\title{
Environmental and health studies of farm workers in Swedish swine confinement buildings
}

\author{
KELLEY DONHAM, ${ }^{1}$ P HAGLIND,${ }^{2}$ YVONNE PETERSON,${ }^{2}$ R RYLANDER,${ }^{2}$ L BELIN $^{3}$ \\ From the Institute of Agricultural Medicine and Occupational Health,' University of Iowa, Iowa City, Iowa \\ 52242, USA, Department of Environmental Hygiene, ${ }^{2}$ University of Gothenburg, S-40033 Gothenburg, and \\ Asthma and Allergy Research Centre, ${ }^{3}$ Department of Medicine I, Sahlgren's Hospital, S-41345 Gothenburg, \\ Sweden
}

ABSTRACT The relation between the health of workers and the environment in swine confinement buildings was investigated in a study of 57 workers on 30 swine farms in southern Sweden and 55 matched controls. Swine workers reported significantly higher frequencies of respiratory symptoms, more frequent colds and absence due to chest illness, and a history of pneumonia. The increased frequency of symptoms of respiratory disease was related to the number of years and per cent of the day spent working with swine. Symptoms were also associated with respirable dust, total dust, endotoxin in total dust, and number of microbes in the air of the work environment. In a multiple regression analysis of the relation between 16 different environmental parameters to work period shifts of five pulmonary function parameters, endotoxin was found to be significantly related to the $\mathrm{FEV}_{1}$ in a dose dependent way.

In recent decades farmers in Europe and North America have enlarged livestock production techniques by using more enclosed and densely stocked housing (confinement buildings). The design of these buildings is similar in that animals, their wastes, and feed are highly concentrated, resulting in high levels of dusts, gases, microbes, microbial metabolites, and other potential health hazards in the air.

In a study in the United States Donham et al found area dust levels of $6.3 \mathrm{mg} / \mathrm{m}^{3}$ on average. 'The amount of respirable dust measured with a cyclone preseparator was $0.53 \mathrm{mg} / \mathrm{m}^{3}$ and with a cascade impactor $2.5 \mathrm{mg} / \mathrm{m}^{3}$. The same study reported that the major sources of dust were feed dust and dry faecal material. Several gases were found including ammonia, hydrogen sulphide, and carbon monoxide. ${ }^{23}$ Of these, ammonia most commonly approached or exceeded threshold limit values (TLV), averaging about 16 parts per million in 21 different swine buildings. High concentrations of hydrogen sulphide were found when manure stored in liquid form was agitated. ${ }^{4}$ A recent report of a study in the Netherlands of 171 swine buildings corroborated these results. ${ }^{5}$

Curtis et al studied airborne bacteria in swine buildings and found that around $30 \%$ of the airborne

\footnotetext{
Accepted 11 January 1988
}

bacteria were less than 5 microns in diameter. ${ }^{6}$ They concluded that the airborne dust was mainly feed dust. Similar results are reported by Bundy and Hazen, ${ }^{7}$ Gordon, ${ }^{8}$ Hill and Kenworthy, ${ }^{9}$ and Horvath et al. ${ }^{10}$ Donham et al found concentrations of viable bacteria at $10^{4}$ colony forming units $(\mathrm{cfu}) \mathrm{m}^{3}$, whereas the number of viable mould species was lower (approximately $\left.\left.10^{3} \mathrm{cfu}\right) \mathrm{m}^{3}\right)$. $^{\prime}$ Gram positive bacteria dominated the microbial flora and the major mould species included Penicillium, Alternaria, Aspergillus, and Fusarium. High numbers of Gram negative bacteria in swine buildings were found by Clark et al. ${ }^{11}$

Gram negative bacteria contain a lipopolysaccharide compound (endotoxin) on their outer cell wall. Endotoxins have high biological potency and relations have been shown between acute symptoms among workers in cotton mills and concentrations of airborne endotoxin. ${ }^{12-15}$ Measurements of airborne endotoxins have been made in swine confinement buildings. Clark et al detected concentrations ranging from 0.04 to $0.28 \mu \mathrm{g} / \mathrm{m}^{3}$ in Sweden ${ }^{11}$ and Donham et al found about the same concentrations in the United States.'

A few studies have evaluated medical effects among workers in piggeries. In 1977 Donham et al reported results from a questionnaire survey which showed that about $70 \%$ of the workers had one or more respiratory symptoms. More detailed studies were reported by Donham in $1982^{16}$ and $1984,{ }^{17}$ which confirmed 
the high prevalence of symptoms of bronchitis, chest tightness, and frequent respiratory infections. Pulmonary function showed significant changes in $\mathrm{FEV}_{1}$ and $\mathrm{FEF}_{25-75}$ over the workday. Baseline pulmonary function, however, did not differ from predicted values.

In Sweden Haglind et al in 1984 studied 63 people employed in swine buildings with a postal questionnaire. ${ }^{18}$ Cough, throat irritation, and chest tightness were commonly reported in connection with work by $18 \%$ of non-smokers and $38 \%$ of smokers. In Canada Holness et al showed excessive respiratory symptoms in swine farmers, ${ }^{19}$ similar to those reported from the studies in the United States and Sweden.

These studies have shown that the air in swine confinement buildings is contaminated with potentially harmful substances and that extensive respiratory symptoms and dysfunction are present among workers. No information is so far available on dose response relations which are needed to define exposure limits. The present study was designed as a first attempt to obtain such information.

\section{Material and methods}

\section{HEALTH DATA}

The population was selected from all large commercial swine farms within the Bjuv district of the Swedish Farmers' Safety and Preventive Association (Lantbrukshälsan). This district covers an area of about $400 \mathrm{~km}^{2}$ in the south west of Sweden. The members of Lantbrukshälsan represent about $35 \%$ of the farm population in this area. Thirty nine farmers in the area were invited by letter to participate in the study and health data were taken from 57 workers on these farms. A control population of 55 matched controls, who were all farmers but not engaged in raising pigs, were selected from a Lantbrukshälsan area near Kristianstad in the south east of Sweden. Climate, socioeconomic considerations, and other factors which may affect health status were similar in the subject and control areas. The controls were pair matched to the swine farm workers by age ( \pm 5 years), sex, and smoking history ( \pm 5 cigarette pack-years).

Health data collected included an interview for occupational history, health history, and symptoms. Pulmonary function testing was done before and after a daily work period. For logistical reasons, respiratory function measurements could not be performed on the controls. A blood sample was collected to test for antibodies to suspected airborne allergens in the work environment.

The questionnaire consisted of two parts, the first asking for specific symptoms (primarily acute respiratory symptoms) that the workers attributed directly to their work in swine buildings. These questions were asked both betore and after the workshift. The questionnnaire was modelled after two questionnaires which have been used extensively in previous farr health studies. ${ }^{216} 19$ The second part of the question? naire consisted of a Swedish translation of the: American Thoracic Society (ATS) epidemiology stant dardisation project questionnaire, ${ }^{20}$ which concere trates on chronic symptoms of respiratory disease. The ATS questionnaire was also used to interview the controls.

Pulmonary function testing (PFT) was performed ifo a travel trailer located so that no one travelled more than $10 \mathrm{~km}$ to the test site before and after work and was carried out before and after the work period whicts ranged from two to eight hours. The procedures described by Ferris ${ }^{20}$ and Gardner ${ }^{21}$ were used with computerised spirometer with flow volume tracing capabilities (Eagle I, Warren E Collins Inc, Braintreẹ, Massachusetts). The spirometer was calibrated statistically at the beginning of each day with a three litre syringe (ANM System Inc, Washington). The technician instructed the subjects on the forced vitat capacity (FVC) procedure and demonstrated the technique.

The highest forced expiratory volume during on second $\left(\mathrm{FEV}_{1}\right)$ and highest FVC were recorded and were not necessarily from the same test. Forcess expiratory flow (FEF) rates were taken from the c1ㅏㅇㄹ with the highest FVC. Values were expressed as $\$$ cent of predicted values for $\mathrm{FEF}_{50}$ and $\mathrm{FEF}_{75}$ for Morris $e t a l^{2}$ and FVC and $F_{1} V_{1}$ from Berglang et al. ${ }^{23}$

In the test after work blood samples were collecte and the serum tested for antibodies to suspected environmental allergens. The antigens includef Micropolyspora faeni and several mould species, such as Penicillium, Aspergillus fumigatus, Alternaria, and Rhizopus. In addition, extracts from swine urine, swing blood, serum albumin, swine epithelium, dust fro swine buildings, and feed for swine were prepared and Dig-ELISA tests were performed according to Beli et al. ${ }^{24}$ In addition, antigenic analysis was performed on these swine antigens and on the dust collected from the swine buildings.

\section{ENVIRONMENTAL MEASURES}

Environmental measurements on airborne dust an microbes were performed inside 30 swine confinemedit buildings on 28 farms. Gravimetric methods ( $35 \mathrm{mph}$ cassettes and filters with personal air pumps) we used to measure dust. Low hygroscopic filters (Geft man) were used to collect total dust and for respirable dust a cyclone preseparator (Casella) was used. Bo respirable and total dust was determined for person and area sampling. Area samples were taken at two different stations with the building at $1.2 \mathrm{~m}$ above the 
floor, at about the midpoint in the width of the room and at one third and two thirds the length of the building, which sites were considered to represent the typical working environment in the building. Endotoxin analysis was performed on the total and the respirable area dust samples and total dust personal samples using the Limulus lysate assay. ${ }^{25}$

Area microbial air sampling was performed at the same sites as the dust sampling. The nuclepore method was used to detect total microbes (viable and nonviable) in the air in 28 of the buildings. ${ }^{26}$ The six stage Andersen sampler was used on seven of the farms and the number of cfu was determined. Selective media were used to determine moulds and different species of bacteria.

Dräger colorimetric tubes were used to measure ammonia, carbon dioxide, and hydrogen sulphide concentrations at several locations in the building, including the two sites where stationary dust and microbes were measured. Measurements were also made in the swine pens at $40 \mathrm{~cm}$ above the floor, at the ventilation inlet, and at the ventilation exhaust. In addition, ammonia was measured by an integrated method sampling over three to four hours. ${ }^{27}$

\section{RELATIONS BETWEEN HEALTH AND}

\section{ENVIRONMENTAL MEASUREMENTS}

The relations between health (acute symptoms, chronic symptoms, baseline PFT, and over work period change in PFT) and the various exposure measures were studied. The environmental measures included (1) exposure time, personal and area sampling for (2) total dust, (3) respirable dust, (4) endotoxin, (5) ammonia, (6) carbon dioxide, and (7) Andersen and nuclepore sampling for bacteria, fungi, viable plus non-viable organisms, respirable organisms, and (8) density of swine in the buildings.

As the acute symptoms were assessed on a graded scale of $0-3$, we were able to analyse by correlation and regression analysis. The ATS questionnaire data were analysed by dividing the farms into four groups (quartiles) according to the levels of each of the air contaminants, whereafter the percentage of workers with symptoms in each group was calculated. When the percentage of workers with symptoms appeared to increase in those quartiles of farms with higher air contamination, the differences were analysed using the $\chi^{2}$ test for four proportions. A $\chi^{2}$ with a $p$ value of $\leqslant 0.05$ was considered indicative of a dose response relation. Baseline PFT values and air contaminants were analysed by correlation and regression. The work period changes ( $\triangle$ PFT) was analysed by multiple regression analysis.

For the multiple regression analysis, known predictor variables of $\triangle \mathrm{PFT}$, including cigarette pack-years, age, and baseline PFT were entered into a multivariate prediction model. The environmental variables (listed above) were then entered as candidates to improve the prediction model. The deviation in predictive value of these variables compared with the known variables (residual values) were correlated with the $\triangle \mathrm{PFT}$ in question, and those with a significant correlation with $\triangle$ PFT were entered back into a multivariate model.

\section{Results}

\section{ENVIRONMENTAL DATA}

The amount of respirable dust in area and personal sampling was about $8 \%$ of the total dust (table 1). For area sampling, the respirable fraction contained about $60 \%$ of the endotoxin activity, or $0.36 \mu \mathrm{g} / \mathrm{mg}$ dust compared with about $0.05 \mu \mathrm{g} / \mathrm{mg}$ dust for total dust.

The number of cfu was about one tenth of the total number (viable plus non-viable) as evaluated with the nuclepore method. The total number of $\mathrm{cfu}$ as measured by the Andersen sampler was less than the number of viable organisms as measured by the nuclepore method. The number of airborne moulds was only about $4 \%$ of the total number of microbes. For moulds, the nuclepore counts and the Andersen counts were the same.

The largest portion of microbes $(88 \%)$ was bacteria. Of the bacteria, Gram positive organisms were the most common (86\%), with Enterococci 7\%, Gram negative $2 \%$, and others unidentified $5 \%$.

Table 1 Airborne concentrations of different contaminants in swine confinement buildings. Area and personal sampling with arithmetic mean and range from 28 buildings and geometric standard deviation

\begin{tabular}{|c|c|c|c|}
\hline Variable & Mean & Range & $S D$ \\
\hline \multicolumn{4}{|l|}{ Dust area: } \\
\hline Total & $4 \cdot 3$ & $1 \cdot 4-8 \cdot 3$ & $2 \cdot 0$ \\
\hline Respirable & $0 \cdot 33$ & & \\
\hline \multicolumn{4}{|l|}{ Dust personal: } \\
\hline Total & $6 \cdot 8$ & $1 \cdot 8-21 \cdot 7$ & $4 \cdot 5$ \\
\hline Respirable & $0 \cdot 34$ & $0-2 \cdot 2$ & 0.4 \\
\hline \multicolumn{4}{|l|}{ Endotoxin $\mu \mathrm{g} / \mathrm{m}^{3}$ area: } \\
\hline Total & 0.18 & $0.04-0.33$ & $0 \cdot 1$ \\
\hline Respirable & 0.17 & $0.01-0.56$ & $0 \cdot 15$ \\
\hline \multicolumn{4}{|c|}{ Endotoxin $\mu \mathrm{g} / \mathrm{m}^{3}$ personal: } \\
\hline Total & $0 \cdot 24$ & $0 \cdot 02-1 \cdot 10$ & $0 \cdot 2$ \\
\hline Respirable & $0 \cdot 23$ & $0.02-1 \cdot 12$ & $0 \cdot \overline{2}$ \\
\hline \multicolumn{4}{|c|}{ Micro-organisms $\times 10^{n} / \mathrm{m}^{2}$ : } \\
\hline Total (nuclepore) & 18 & 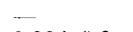 & - \\
\hline Viable (nuclepore) & $1 \cdot 4$ & $0.004-8.3$ & \\
\hline Cfu (Andersen) & 0.45 & $0.23-0.71$ & $0 \cdot 2$ \\
\hline \multicolumn{4}{|l|}{ Bacteria $\times 10^{6} / \mathrm{m}^{3}$ : } \\
\hline Total (nuclepore) & $1 \cdot 4$ & $0 \cdot 05-8 \cdot 3$ & $2 \cdot 1$ \\
\hline Cfu (Andersen) & $0 \cdot 4$ & $0 \cdot 2-0.6$ & $0 \cdot 2$ \\
\hline \multicolumn{4}{|l|}{ Moulds $\times 10^{n} / \mathrm{m}^{?}:$} \\
\hline Total (nuclepore) & $0 \cdot 02$ & $0.001-0.3$ & $0 \cdot 1$ \\
\hline Cfu (Andersen) & 0.02 & $0.002-0.09$ & 0.03 \\
\hline Ammonia (ppm) & 9 & $3 \cdot 3-25$ & $5 \cdot 2$ \\
\hline Carbon dioxide (ppm) & 1740 & $900-4500$ & 851 \\
\hline Hydrogen sulphide & \multicolumn{3}{|c|}{ Not detected } \\
\hline
\end{tabular}

- Indicates measurements not carried out. 


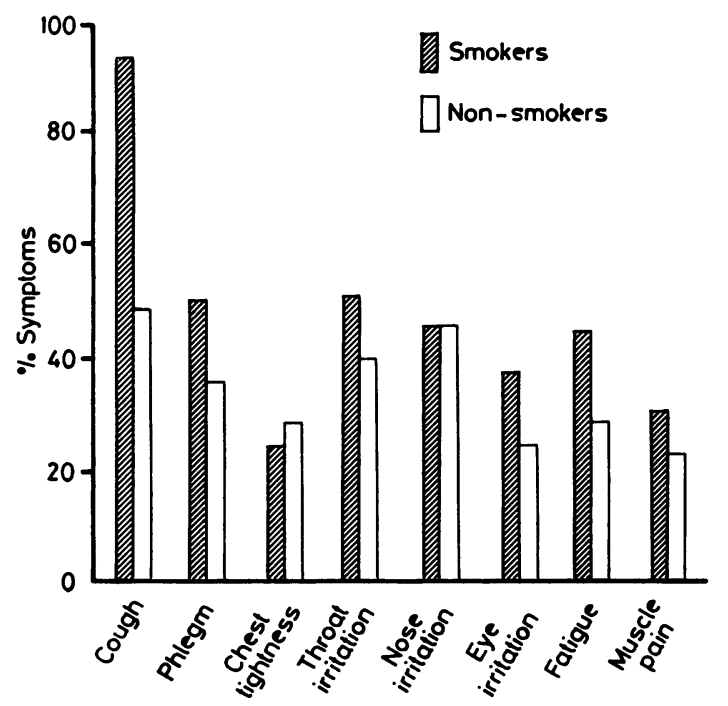

Fig 1 Work related symptoms reported among workers in swine confinement buildings. Non-smokers = never smokers plus ex-smokers. Difference for cough is significant $\left(\chi^{2} \leqslant 0.05\right)$.

\section{HEALTH STUDIES}

Figure 1 summarises the most significant findings from the questionnaire designed to assess work related symptoms. Symptoms of cough or phlegm were common, with $60 \%$ of the workers reporting cough and $40 \%$ reporting cough with phlegm. Chest tightness was reported by $28 \%$ of the workers. Eye, nose, and throat irritation were also commonly reported $(28 \%, 41 \%$, and $34 \%$, respectively). Compared with non-smokers, smokers had a higher prevalence of cough, phlegm, throat irritation, and fatigue. The $\chi^{2}$ value comparing cough in smokers and non-smokers was significant $(p \leqslant 0.05)$. There was no significant difference between smokers and non-smokers in development of chest tightness or nose irritation ove $\overline{\bar{S}}$ the workshift.

Cough and cough with phlegm were reported by $\frac{\Phi}{8}$ higher proportion of the swine workers than the controls (table 2). Wheezing with a cold, frequen $\overline{\bar{B}}$. chest colds, work absence due to chest illness, and history of pneumonia were also reported about twice as frequently by the swine workers. Bronchitic symp $\overline{\bar{A}}$. toms in smoking workers were twice as frequent as i non-smoking workers and nine times as frequent a $\mathrm{a}$ bronchitic symptoms in non-smoking controls. NQ difference between smokers and non-smokers was found for "frequent chest colds," which were two to. three times more common among swine workers that among controls. Reports on history of pneumonia a referred to adult pneumonia and had been verified by $\$$ physician. Pneumonia was most common among non: smoking workers.

Mean baseline $\mathrm{FEF}_{50}$ and $\mathrm{FEF}_{75}$ in the swines workers were $84 \%$ and $60 \%$ of predicted values $(p \leqslant 0.05)$. The mean ratio of FEV , to FVC was $75 \%$ and mean baseline FVC and $F E V_{1}$ were within $95 \%$ of predicted values. The differences between smokers and non-smokers were small but statistically significant decreases in PFT were found over the workshift $\mathrm{FEF}_{50}(6 \%)$ and $\mathrm{FEV}_{75}(4.3 \%)$ in smokers (Wilcoxob matched pairs, signed rank test, $p \leqslant 0.05$ ) (fig $220^{\circ}$ Nearly $50 \%$ of the workers experienced a decremenip FEV 1 and FVC over the work period but the meas value was small and non-significant.

Positive dig-ELISA serology tests to swine antigens were seen in about $10 \%$ of the workers and $10 \%$ of the controls. There were no significant differences im strength of antigen-antibody reaction between swinê workers and controls.

\section{ASSOCIATIONS BETWEEN HEALTH DATA AND EXPOSURE}

Cough in non-smokers and fever episodes in smokere? were significantly related to respirable dust collecteg

Table 2 Per cent of swine confinement workers (SWC) and controls (C) reporting chronic respiratory symptoms (ATS (tuestionnaire)

\begin{tabular}{|c|c|c|c|c|c|c|}
\hline & \multicolumn{2}{|l|}{$A l l$} & \multicolumn{2}{|c|}{ Smokers } & \multicolumn{2}{|c|}{ Non-smokers $\frac{D}{2}$} \\
\hline & $S C W$ & $C$ & $S C W$ & $C$ & $S C W$ & $C$ 三. \\
\hline $\begin{array}{l}\text { No of workers } \\
\text { Cough } \\
\text { Cough with phlegm } \\
\text { Cough with phlegm ( } 3 \text { weeks) } \\
\text { Wheering with a cold } \\
\text { Wheezing without a cold } \\
\text { Wheezing most of the time } \\
\text { Frequent chest colds } \\
\text { Off work due to chest illness } \\
\text { History pneumonia }\end{array}$ & $\begin{array}{l}57 \\
39 * * \\
16 \\
7 \\
21 \\
12 \\
4 \\
53^{* * *} \\
30 \\
16\end{array}$ & $\begin{array}{r}55 \\
13 \\
7 \\
4 \\
13 \\
16 \\
2 \\
20 \\
18 \\
6\end{array}$ & $\begin{array}{r}16 \\
63 \\
25 \\
6 \\
25 \\
31 \\
13 \\
50 \\
31 \\
7\end{array}$ & $\begin{array}{r}14 \\
29 \\
21 \\
14 \\
14 \\
21 \\
0 \\
21 \\
14 \\
14\end{array}$ & $\begin{array}{l}41 \\
29^{*} \\
12 \\
15 \\
20 \\
5 \\
0 \\
54^{*} \\
29 \\
17\end{array}$ & טָ \\
\hline
\end{tabular}




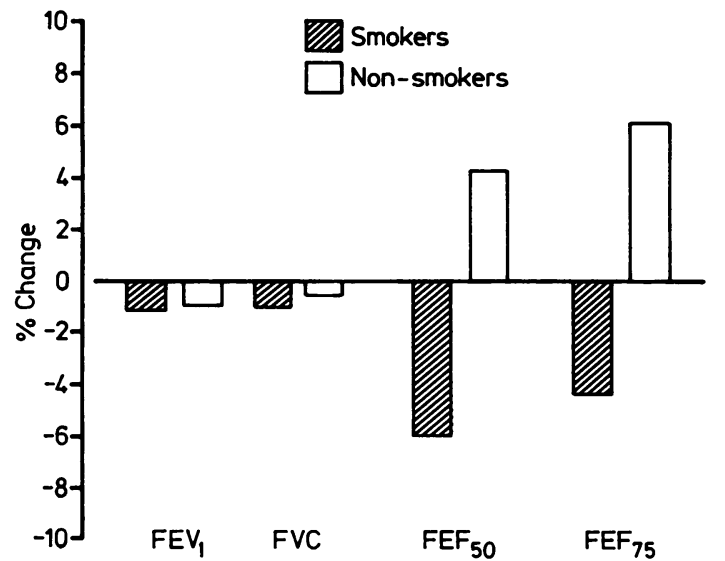

Fig 2 Average pulmonary function changes over work period in per cent from 29 non-smokers and 28 smokers. Decrease in $F F_{75}$ significant (Wilcoxon matched - pairs signed - ranks test $p \leqslant 0.05)$.

by personal sampling (Pearson analysis $r=0.4$, $\mathrm{p}=0.04$ and $\mathrm{r}=0.98, \mathrm{p}=0.0001$ respectively). Work related chest tightness and dyspnoea in nonsmokers were correlated to the number of mould spores in the air $(r=0.9, p=0.0009$ and $r=0.7$, $\mathrm{p}<0.001$, respectively). The presence of febrile episodes in smokers was related to personal respirable dust.

The results of the analysis of relations between chronic symptoms and environmental exposure are summarised in table 3.

Table 4 shows the per cent of non-smoking workers with chronic bronchitis according to years of work exposure. Symptoms were more common among swine workers than among controls and were related to the number of years spent working with swine. The relation between chronic bronchitis and number of years working in confinement buildings was corroborated by a significant relation of years at work to the baseline value of $\mathrm{FEF}_{75}$ (Spearman, $\mathrm{r}=\mathbf{0 . 8 0}$ for non-smokers, $r=0.31$ for smokers, $p \leqslant 0.05$ ). For both smokers and non-smokers working more than 10 years the flow rates were $20 \%-80 \%$ (mean $40 \%$ ) of predicted values.

Per cent of time working with swine was also associated with chronic bronchitis. The proportion of workers with cough and phlegm, occurring for more than three years, was significantly higher among confinement workers than among controls when more than $25 \%$ and $40 \%$, respectively, of the working day was spent with swine ( $t$ test, $\mathrm{p} \leqslant 0.05$ ).

Regarding the relation between changes in baseline or PFT and environmental contaminants, correlations, single regression, and multiple regression analyses were performed. In general, the results were similar to those associations seen between symptoms and environmental exposure. The most consistent and significant correlations with pulmonary function were with number of years working in swine buildings, per cent time each day working in swine buildings, total and respirable dust measured by personal samples, and endotoxin measured by area sampling.

Statistically significant correlations (Pearson $p<0.05$ ) were found between ammonia and $F F_{75}$ $(r=0.38)$ and carbon dioxide and $\mathrm{FEF}_{75}(r=0.40)$. These correlations were present in both smokers and non-smokers. Ammonia concentrations above $7 \mathrm{ppm}$ and carbon dioxide concentrations above $1540 \mathrm{ppm}$ were associated with decreased baseline flow rates, $\mathrm{FEV}_{50}$ and $\mathrm{FEF}_{75}$.

Regression analysis of the correlation between per cent time a day working in the building and $\triangle$ PFT was statistically significant $(p \leqslant 0.05)$. There was not, however, a significant regression with total years worked in buildings or number of hours worked on the day of testing.

When looking at non-smokers by regression analysis, a significant dose response relation (PR $>F$ $0.004)$ was seeen between $\triangle F E V_{1}$ and endotoxin measured in total dust from area samples. Figure 3 shows that decrement in $\mathrm{FEV}_{1}$ over a workshift began at exposures of about $0.18 \mu \mathrm{g} / \mathrm{m}^{3}(90 \%$ confidence limits $=0-0.44)$. A similar analysis with non-smokers did not show the same dose response relation. Dose response relation was also seen for $\triangle F E F_{75}$ and endotoxin, although the regression line was not as steep or as highly statistically significant $(p \leqslant 0.05)$ as with $\triangle F E V^{i}$. Over workshift, decrements were noted with exposure to endotoxin above $0.27 \mu \mathrm{g} / \mathrm{m}^{3}$.

No significant workshift decrements were associated with endotoxin as measured in respirable dust samples. Smokers were too few in numbers for a similar regression analysis to be carried out.

Although endotoxin was the most important single

Table 3. Levels of environmental contaminants in swine buildings associated with excess respiratory symptoms in workers (chronic symptoms ATS questionnaire) relative to controls ( $\chi^{2}$ test for four proportions $p \leqslant 0.05$ )

\begin{tabular}{|c|c|c|c|c|}
\hline & $\begin{array}{l}\text { Endotoxin area total } \\
\left(\mu \mathrm{g} / \mathrm{m}^{3}\right)\end{array}$ & $\begin{array}{l}\text { Dust area total } \\
\left(m g / m^{3}\right)\end{array}$ & $\begin{array}{l}\text { Dust personal respirable } \\
\left(\mathrm{mg} / \mathrm{m}^{\mathrm{r}}\right)\end{array}$ & $\begin{array}{l}\text { Airborne hacteria (all) } \\
\left(\left(\mathrm{fu} / \mathrm{m}^{3}\right)\right.\end{array}$ \\
\hline Chronic cough and phlegm & 0.09 & $2 \cdot 4$ & $0 \cdot 3$ & \\
\hline Wheezing with cold & 0.1 & & & $10^{3}$ \\
\hline Wheezing without a cold & $0 \cdot 22$ & & & \\
\hline Frequent chest colds & $0 \cdot 1$ & $3 \cdot 6$ & 0.4 & $10^{3}$ \\
\hline Febrile episodes & $0 \cdot 3$ & & 0.4 & \\
\hline
\end{tabular}


Table 4 Chronic bronchitis (cough and phlegm for three or more months of the year for three consecutive years) among non-smoking swine confinement workers relative to years working with swine, and among control farm workers. Controls matched for years worked, sex, age ( $\pm 5 y$ ), and cigarette pack-years ( $\pm 5 y$ )

\begin{tabular}{lccl}
\hline & Controls & \multicolumn{2}{c}{ Swine workers } \\
\hline Work years & 29 & $1-13$ & $14-30$ \\
No studied & 7 & 21 & 23 \\
Bronchitis: & 7 & 8 & 14 \\
No & 13 & $38^{*}$ & $61^{* * *}$ \\
Per cent & & & \\
\hline
\end{tabular}

${ }^{*} \mathrm{p} \leqslant 0.05 ;{ }^{* * *} \mathrm{p} \leqslant 0.001$.

environmental predictor of $\triangle F E V_{1}$, we also investigated the interaction with other predictors in a multiple regression model. A highly significant predictive model (PR $>$ F 0.003) for $\triangle F E V_{1}$ was described which included the factors of cigarette smoking history in pack-years (Py), baseline $\mathrm{FEV}_{1}\left(\mathrm{~V}_{1}\right)$, and endotoxin (E), according to the following equation:

$$
\begin{aligned}
\text { FEV }_{1}= & 11 \cdot 5-\left(0 \cdot 079 \cdot \mathrm{V}_{1}\right)-(0 \cdot 35 \cdot \mathrm{Py})+ \\
& \left(0 \cdot 003 \cdot \mathrm{V}_{1} \cdot \mathrm{Py}\right)-(1 \cdot 62 \cdot \mathrm{E}) .
\end{aligned}
$$

Calculations were made of the values for each environmental contaminant, above which the symptoms of PFT were greater than those found in controls. Table 5 lists the levels at significant decrements in baseline PFT which were found.

In addition, over shift decrements in PFT occurred at total dust, personal sampling values above $3.8 \mathrm{mg}$ / $\mathrm{m}^{3}$, endotoxin total, dust area sampling above $0.08 \mu \mathrm{g} /$ $\mathrm{m}^{3}$, and carbon dioxide above $0 \cdot 15 \%$.

Although tentative and based on a limited material, these values could be used as provisional guidelines for maximum exposures.

\section{Discussion}

This study has confirmed previous studies which showed an increased prevalence of subjective and

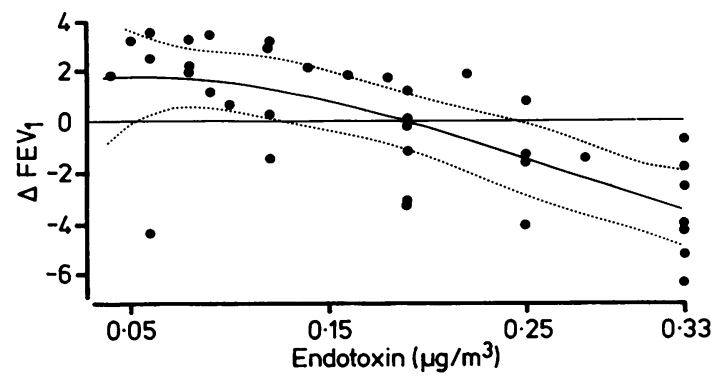

Fig 3 Change in per cent predicted FEV in non-smoking swine farmers over work period relative to area endotoxin concentrations in total dust; regression line with $90 \%$ confidence limits $(P R>F 0.004) \triangle F E V_{1}=4.2-$ $(23 \cdot 258 \cdot E)$, where $E=$ endotoxin.
Table 5 Exposure levels for air contaminants in swine buildings where significant decrements in baseline PFT were present as compared with controls

Total dust $\mathrm{mg} / \mathrm{m}^{3}$ :

Personal sampling $\quad 3.8$

Area sampling

Respirable dust $\mathrm{mg} / \mathrm{m}^{3}$ :

Personal sampling

$2 \cdot 4$

Area sampling

Endotoxin $\mu \mathrm{g} / \mathrm{m}^{3}$ :

Personal sampling

Area sampling (total)

Carbon dioxide (\%)

Ammonia (ppm)

Total microbes (cfu)

Bacteria cfu $10^{6} / \mathrm{m}^{3}$

Moulds cfu/m

Total microbes microscopic count $/ \mathrm{m}^{3}$

Respirable microbes microscopic count $/ \mathrm{m}^{3}$

objective pulmonary effects in subjects working swine confinement buildings. ${ }^{216-18}$ The symptoms des-cribed are similar to those reported by people exposesp to other types of organic dusts, grain dusts, for example. ${ }^{28}$ An increased rate of symptoms of bronchitis and respiratory infections resulting in increased loss of worktime were the most important findings Typical symptoms of farmer's lung (allergic alveolitis were not found. As, however, the prevalence of this disease in risk populations does not generally excees $1 \%$ it would have been unlikely to occur in a stgdo of this size. As in previous studies in the Unied States ${ }^{16}{ }^{17}$ this study also showed that febrile episgd suggestive of organic dust toxic syndrome occup 语 swine workers. ${ }^{29}$

This is the first study to show quantitative relations between exposure and health measures in the swine confinement environment. The major finding was the dose response relation between over work period change in $\mathrm{FEV}_{1}$ and area total endotoxin levels. This similar to those from investigations on other dusts. containing endotoxin, particularly cotton dust. ${ }^{12 . \Phi^{3}}$ This dose response relation also documents the biological activity of swine house dust, indicating that nuisance dust standards are not applicable.

The threshold level of endotoxin relative to FE民 decrement was about $0.2 \mu \mathrm{g} / \mathrm{m}^{3}$. Eighty five per cent of the individuals had decrements over the workine period if endotoxin values were $>0.2 \mu \mathrm{g} / \mathrm{m}^{3}$, wherears $11 \%$ experienced decrements with exposure values. $<0.2 \mu \mathrm{g} / \mathrm{m}^{3}$. This agrees with experimental resultog from studies on cotton dust. ${ }^{12} 13$ Endotoxin, however, is not the only hazardous substance in this envirop ment as other environmental contaminants, including dust and microbes, were also related to respirato symptoms or a decrease in baseline PFT values. dose response analysis is complicated in multivariabe studies, however, additional studies are needed to document these findings.

Baseline flow rates at $25 \%$ and $50 \%$ of lung volum were decreased with respect to predicted values. The correlation between decreased baseline PFT and 
several environmental parameters (table 5) suggest that a chronic inflammation in the airways is the most important effect after exposure to dust in swine buildings.

In previous studies of health effects of organic dusts, particularly cotton dust, much attention has focused on PFT changes over the workshift. In the present study small decrements of this type were observed but they were significant only in smokers. Although it is difficult to know whether or not these changes were due to the working environment, or smoking, or a combination of both, multiple regression analysis did show a suggestive dose response relation between FEF $_{75}$ and endotoxin $(p=0.055)$. Previous studies showed similar findings in that decrements in $F_{E F}$ and $\mathrm{FEF}_{75}$ were the most significant changes over workshift but the changes were seen equally in nonsmokers and smokers. ${ }^{16}$ The magnitude of the decreased $\mathrm{FEF}_{50}$ and $\mathrm{FEF}_{75}$ identified here is not of direct functional relevance to the workers but indicates a risk for a development of chronic inflammation, later demonstrable by decreases in baseline PFT.

Most of the acute symptoms found in the study relate to the discomfort of the workers. This probably implies decreased worker productivity and loss of worktime. Other acute health problems were difficult to document. Since we studied healthy workers, we do not know what happens to those most severely affected but similar symptoms have been shown in grain workers who have dropped out of the workforce. ${ }^{26}$ Therefore, we have only a partial picture of the risk for acute respiratory illness present among workers in swine buildings.

The evidence of respiratory disease documented in this and previous studies supports the need for control programmes to protect workers. The main objectives of such a programme should be to prevent discomfort and the loss of worktime that is seen from bronchitis and respiratory infections and to prevent the development of chronic disease. The evidence in this study for threshold levels of air contaminants associated with excess symptoms and pulmonary dysfunction should be considered preliminary in nature. Nevertheless, the information could, for the time being, be used as provisional guidelines to protect workers.

This study was funded by the Swedish Work Environment Fund contracts 82-0101, 83-0124, 83-0933, and 84-0667.

\section{References}

1 Donham KJ, Scallon L, Popendorf WJ, Treuhaft M, Roberts R. Characterization of dusts collected from swine confinement buildings. Am Ind Hyg Assoc J 1986;47:404-10.

2 Donham KJ, Rubino M, Thedell TD, Kammermeyer J. Potential health hazards to agricultural workers in swine confinement buildings. J Occup Med 1977;19:383-7.

3 Donham KJ, Popendorf WJ. Ambient levels of selected gases inside swine confinement buildings. Am Ind Hyg Assoc J 1985; 46:658-61.

4 Donham KJ, Knapp LW, Monson R, Gustafsson KE. Acute toxic exposure to gases from liquid manure. $J$ Occup Med 1982; 24:142-45.

5 Altwood P, Brouwer R, Ruigewaard P, et al. A study of the relationship between airborne contaminants and environmental factors in Dutch swine confinement buildings. Am Ind Hyg Assoc J 1987;48:745-51.

6 Curtis SE, Drummond JG, Grunloh DJ, Brendan Lynch P, Jensen AH. Relative and qualitative aspects of aerial bacteria and dust in swine houses. J Anim Sci 1975;41:1512-20.

7 Bundy DS, Hazen TE. Particle-size characterization of dust in swine confinement systems. Am Soc Agr Eng Paper, 1973; MC73-501.

8 Gordon WAM. Environmental studies in pig housing IV. The bacterial content of air in piggeries and its influence on disease incidence. $\mathrm{Br}$ Vet $J$ 1963;119:263-73.

9 Hill IR, Kenworthy R. Microbiology of pigs and their environment in relation to weaning. $J$ Appl Bacteriol 1970;33:299-316.

10 Horvath DJ, Peterson ME, Clawson AJ, Sheffy BE, Loosli JK. Diurnal variations in the composition of swine feces. J Anim Sci 1958;17:869-74.

11 Clark CS, Rylander R, Larsson L. Airborne bacteria, endotoxin and fungi in dust poultry and swine confinement buildings. $\mathrm{Am}$ Ind Hyg Assoc J 1983;44:537-41.

12 Castellan RM, Olenchock SA, Hankinson JG, et al. Acute bronchoconstriction induced by cotton dust: dose-related responses to endotoxin and other dust factors. Ann Intern Med 1984;101:157-63.

13 Rylander R, Haglind P, Lundholm $M$. Endotoxin in cotton dust and respiratory function decrement among cotton workers in an experimental cardroom. Am Rev Respir Dis 1985;131:209-13.

14 Rylander R, Haglind P. Exposure of cotton workers in an experimental cardroom with reference to airborne endotoxins. Environ Health Perspect 1986;66:83-6.

15 Petsonk EL, Olenchock SA, Castellan RM, et al. Human ventilatory response to washed and unwashed cottons from different growing areas. $\mathrm{Br} J$ Ind $\mathrm{Med}$ 1986;43:182-7.

16 Donham KJ, Gustafsson KE. Human occupational hazards from swine confinement. Annals of the American Conference of Governmental Industrial Hygienists 1982;2:137-42.

17 Donham KJ, Zavala DC, Merchant JA. Acute effects of the work environment on pulmonary functions of swine confinement workers. Am J Ind Med 1984;5:367-76.

18 Haglind P, Rylander R, Clark CS. Respiratory function among workers in swine confinement buildings. In: Bernard J, Gee L, Morgan KC, Stuart M, eds. Occupational lung disease. New York: Raven Press, 1984:228.

19 Holness DL, O'Blenis EL, Sass-Kortsak A, Pilger C, Nethercott JR. Respiratory effects and dust exposures in hog confinement farming. Am J Ind Med 1987;11:571-80.

20 Ferris BG. Recommended standardized procedures for pulmonary function testing in epidemiology standardization projects. Am Rev Respir Dis 1978;118:57-88.

21 Gardner RM. ATS statement - snowbird workshop on standization of spirometry. Am Rev Respir Dis 1979;119:831-8.

22 Morris JF, Koski A, Johnson LC. Spirometric standards for healthy nonsmoking adults. Am Rev Respir Dis 1971;103:57-67.

23 Berglund E, Birath G, Bjure J, et al. Spirometric studies in normal subjects. I. Forced expirograms in subjects between 7 and 70 years of age. Acta Med Scand 1963;173:185-92.

24 Belin L, Eriksson N, Malmberg P. Antibodies to microbial antigens in various farm populations. Am J Ind Med 1986; 10:277-80.

25 Rylander R, Morey P. Airborne endotoxin in industries processing vegetable fibers. Am Ind Hyg Assoc J 1982;43:811-2.

26 Palmgren U, Ström G, Malmberg P, Blomquist G. The nucleporfilter method: a technique for enumeration of viable and non-viable airborne microorganisms. Am J Ind Med 1986;10:325-7.

27 Rudling J, Hallberg B, Hultenberg M, Hultman A. Development and evaluation of field methods for ammonia in air. Scand $J$ Work Environ Health 1984;10:197-202.

28 James AL, Cookson WOCM, Buters G, et al. Symptoms and longitudinal changes in lung function in young seasonal grain handlers. Br J Ind Med 1986;43:587-91.

29 doPico GA. Report on diseases. Am J Ind Med 1986;10:261-5. 